\title{
Dynamics of Nitrogen Gaseous Losses Following the Application of Foliar Nanoformulations to Grasslands
}

\author{
Sara Hube ${ }^{1} \cdot$ Francisco Salazar $^{1} \cdot$ Marion Rodríguez $^{1} \cdot$ Jaime Mejías $^{2} \cdot$ Luis Ramírez $^{1} \cdot$ Marta Alfaro $^{1}$ (i)
}

Received: 27 September 2021 / Accepted: 11 January 2022 / Published online: 18 January 2022

(c) The Author(s) 2022

\begin{abstract}
Increasing rates of nitrogen $(\mathrm{N})$ conventional fertilizer have led to increasing risks of $\mathrm{N}$ losses to the atmosphere, mainly as ammonia $\left(\mathrm{NH}_{3}\right)$ and nitrous oxide $\left(\mathrm{N}_{2} \mathrm{O}\right)$. The aim of this study was to evaluate the effect of foliar $\mathrm{N}$-based nanoformulations on the dynamics of $\mathrm{N}_{2} \mathrm{O}$ and $\mathrm{NH}_{3}$ emissions from grasslands. Six $\mathrm{N}$ treatments $\left(50 \mathrm{~kg} \mathrm{~N} \mathrm{ha}^{-1}\right)$ plus a control $(n=4)$ were tested on a completely randomized design: granular urea (Urea-g), dissolved urea (Urea-d), dissolved ammonium nitrate $\left(\mathrm{NH}_{4} \mathrm{NO}_{3}\right)$, and nitrate-, urea-, and ammonium-based nanoformulations $\left(\mathrm{NO}_{3}-\mathrm{F}\right.$, Urea-F, $\left.\mathrm{NH}_{4}-\mathrm{F}\right)$ applied as foliar spray to intact soil cores maintained under controlled conditions. In addition, a control $N=0$ was included. Cumulative emissions of $\mathrm{N}_{2} \mathrm{O}$ and $\mathrm{NH}_{3}\left(\mathrm{mg} \mathrm{N} \mathrm{m}^{-2}\right)$ were measured using dynamic/static chambers. Effects on yield and soil available $\mathrm{N}$ were also quantified. Volatilization of $\mathrm{NH}_{3}$ was the main $\mathrm{N}$ loss pathway (ranged from 2 to $51 \%$ of the $\mathrm{N}$ applied). Higher emissions were observed with $\mathrm{NH}_{4}-\mathrm{F}$ and low emissions in the nitrate-based fertilizers. Direct $\mathrm{N}_{2} \mathrm{O}$ losses were low compared to $\mathrm{NH}_{3}$ losses, varying between 0.07 and $0.25 \%$ of the $\mathrm{N}$ applied. Due to high $\mathrm{NH}_{3}$ losses, indirect $\mathrm{N}_{2} \mathrm{O}$ losses were 0.3 to 2.8 times greater than direct $\mathrm{N}_{2} \mathrm{O}$ losses. There was no effect of $\mathrm{N}$ treatments on soil available $\mathrm{N}$ or pasture yield. The application of a $\mathrm{NO}_{3}$-foliar formulation emerges as a potential alternative for the mitigation of integrated $\mathrm{N}$ gaseous emissions. Ammoniumbased nanoformulations require improvements in order to reduce losses. Further studies should include yield evaluations under field conditions, cost-benefit analysis, and potential impacts in the agri-food chain.
\end{abstract}

Keywords Ammonia volatilization · Nitrous oxide emissions $\cdot$ Nanoformulation $\cdot$ Foliar fertilization $\cdot$ Nitrogen losses reduction

\section{Introduction}

Urea is the most used synthetic nitrogen $(\mathrm{N})$ fertilizer among farmers, accounting for more than $70 \%$ of worldwide fertilizer usage due to its high $\mathrm{N}$ concentration and low cost per unit of nutrient (Driver et al. 2019). Increasing amounts of $\mathrm{N}$-based fertilizers, such as urea, have been used to sustain forage yields for cattle production based on direct grazing of permanent grasslands (de Klein et al. 2017; Oenema et al. 2014). Cropping and grasslands systems of southern Chile are commonly fertilized with granular urea with a $\mathrm{N}$ supply

Marta Alfaro

malfaro@inia.cl

1 Instituto de Investigaciones Agropecuarias, INIA Remehue, Ruta 5 sur km 8, Osorno, Chile

2 Instituto de Investigaciones Agropecuarias, INIA Carillanca, Temuco, Chile ranging from 45 to $300 \mathrm{~kg} \mathrm{~N}^{-1}$ (Alfaro et al. 2018; Alfaro and Salazar 2005; MMA 2020; Mora et al. 2007).

Intensification of $\mathrm{N}$ fertilization has raised general concern regarding large $\mathrm{N}$ losses to the atmosphere (Sun et al. 2008). Gaseous losses due to $\mathrm{N}$ fertilizer application occur mainly as ammonia $\left(\mathrm{NH}_{3}\right)$ volatilization and nitrous oxide $\left(\mathrm{N}_{2} \mathrm{O}\right)$ emissions, both of which are important pollutant products of local agronomic activity (Alfaro et al. 2018). Ammonia has been associated with soil acidification, acid particulate matter and rainfall, and odors (Aneja et al. 2009) and has indirectly been linked to $\mathrm{N}_{2} \mathrm{O}$ and global warming (IPCC 2014a; Tian et al. 2020). Nitrous oxide is a potent greenhouse gas (GHG) which contributes to the depletion of the ozone layer (Matheyarasu et al. 2016). Worldwide, 12\% of $\mathrm{N}_{2} \mathrm{O}$ losses are attributed to synthetic fertilizers applied to agricultural soils (IPCC 2014b).

Worldwide, optimum fertilizer rate is largely dependent on soil $\mathrm{N}$ status and crops or grasslands requirements. Nitrogen applied as urea directly to soil surface is usually 
followed by significant losses via $\mathrm{NH}_{3}$ volatilization (Pan et al. 2016; Salazar et al. 2012; Silva et al. 2017), denitrification (Alfaro et al. 2018; IPCC 2014a), and leaching (Leip et al. 2015). These losses are associated to the several transformations of the $\mathrm{N}$ fertilizer occurring in the soil providing ammonium (ammonification) and/or nitrate (nitrification), for N plant uptake (Cameron et al. 2013), which in turn, potentially leads to low nitrogen use efficiency (NUE).

In an effort to mitigate $\mathrm{N}$ loss pathways and increase NUE, sustainable agricultural practices have been proposed, including urease and nitrification inhibitors and controlledrelease fertilizers (Krol et al. 2020). Application of these compounds when used together with granular urea in soils have resulted in up to $44 \%$ reduction of $\mathrm{N}_{2} \mathrm{O}$ emissions (Alfaro et al. 2018). However, limited effects have been found on pasture (Blennerhassett et al. 2006; Vistoso et al. 2012) and crops yield and $\mathrm{N}$ uptake (Cayuela et al. 2016; Hube et al. 2017). Foliar fertilization using mainly urea as a source of $\mathrm{N}$ has been suggested as an option to reduce total fertilizer input and minimize $\mathrm{N}$ runoff in turfgrass (Liu et al. 2008; Quin et al. 2015); however, the ubiquitous condition of urease enzyme in plant leaves and also environmental factors may exacerbate $\mathrm{NH}_{3}$ losses after urea hydrolysis (Blennerhassett et al. 2006). Foliar $\mathrm{N}$ application, using conventional or enhanced fertilizers dissolved in water, has been evaluated in order to increase NUE due to immediate $\mathrm{N}$ availability (Dimkpa et al. 2020); nevertheless, the rapid availability may result in high $\mathrm{N}-\mathrm{NH}_{3}$ losses to the atmosphere associated to urease activity, as previously explained.

The use of materials with dimensions up to $100 \mathrm{~nm}$ has been proposed as innovative nutrient carriers known as nanofertilizers (Adisa et al. 2019; Dhir 2021; Shang et al. 2019). These nanomaterials have unique properties such as a high surface-to-volume ratio, targeted sites and sorption capacity, and penetration capability into plant leaves, favoring the release of accurate amounts of nutrients in order to match plant's demand (Agrahari and Dubey 2020; Hong et al. 2021; Sidorowicz et al. 2019; Zulfiqar et al. 2019). In particular, $\mathrm{N}$ nanofertilizers have been developed for soil application in crops (Benício et al. 2016; Chhowalla 2017; Kottegoda et al. 2017; Preetha and Balakrishnan 2017); however, there is limited information regarding application and the potential environmental implications of $\mathrm{N}$ nanofertilizers in grasslands (Mejías et al. 2021). Thus, research on the dynamics of $\mathrm{N}$ gaseous losses from grassland systems after nanoformulation application is needed.

Andisols have been described to have strong N sorption-mainly as ammonium $\left(\mathrm{NH}_{4}^{+}\right)$- that would potentially reduce available $\mathrm{N}$ in soil solution for $\mathrm{N}$ uptake in crops and grasslands (Cardenas et al. 2013; Huygens et al. 2007; Salazar et al. 2012). In addition, soil nutrient retention together with high inputs of synthetic fertilizers have contributed to forage $\mathrm{N}$ surplus, increasing the risk of nitrate toxicity for animal consumption (Anrique 2014; Pacheco and Waghorn 2008). We suggest that foliar application of an enhanced $\mathrm{N}$ nanoformulation could affect $\mathrm{N}$ cycling in pastures by overcoming the inherent $\mathrm{NH}_{4}{ }^{+}$soil sorption, increasing plant availability through foliar application, and reducing potential losses to the wider environment from pasture systems. Accordingly, the aim of this study was to evaluate under controlled conditions the $\mathrm{N}_{2} \mathrm{O}$ and $\mathrm{NH}_{3}$ losses from a permanent grassland system, following the application of foliar nanoformulations compared to conventional $\mathrm{N}$ fertilizers.

\section{Materials and Methods}

\subsection{Site Characterization and Soil Used in Lysimeters}

The experiment was carried out under controlled conditions, using an Andisol (Typic Hapludands; CIREN 2003), from a grassland site with a 2-year-old perennial ryegrass (Lolium perenne $\mathrm{L}$.), with no recent $\mathrm{N}$ fertilization or livestock grazing (2 years). The site was located at the Instituto de Investigaciones Agropecuarias, INIA Remehue (40'31 $\mathrm{S}, 73^{\prime} 03^{\circ} \mathrm{W}, 65 \mathrm{~m}$ above sea level). This soil was chemically and physically characterized $(n=4,0-15-\mathrm{cm}$ depth, Table S1), following the methods compiled by Sadzawka et al. (2006) and outlined by Rowell (1997), respectively.

\subsection{Experimental Design}

An experiment was performed using intact soil cores collected from a $L$. perenne pasture $(n=28,0-15-\mathrm{cm}$ depth) and assembled into PVC lysimeters of $9.7 \mathrm{~cm}$ inner diameter and $20.0 \mathrm{~cm}$ height. Plants contained in the soil cores were trimmed at $7 \mathrm{~cm}$ over soil surface the day before $\mathrm{N}$ application. Six $\mathrm{N}$ treatments were applied (Table S2), each one at an equivalent rate of $50 \mathrm{~kg} \mathrm{~N} \mathrm{ha}^{-1}$ $\left(5,000 \mathrm{mg} \mathrm{N} \mathrm{m}^{-2}\right)$ : granular urea (Urea-g, $\left.46 \% \mathrm{~N}\right)$, dissolved urea (Urea-d, $46 \% \mathrm{~N}$ ), ammonium nitrate $\left(\mathrm{NH}_{4} \mathrm{NO}_{3}\right.$, $33 \% \mathrm{~N}$ ), and three novel-based nanoformulations including nitrate $\left(\mathrm{NO}_{3}-\mathrm{F}, 4.3 \% \mathrm{~N}\right)$, urea (Urea-F, $\left.0.8 \% \mathrm{~N}\right)$, and ammonium $\left(\mathrm{NH}_{4}-\mathrm{F}, 6.0 \% \mathrm{~N}\right)$. Granular urea was applied directly to the soil to mimic the conventional practice of farmers, while remaining treatments were dissolved in ultrapure water (1:2) and applied as a foliar spray (Fig. S1a). A treatment without $\mathrm{N}$ was included as control (Table S2). Nanoformulations were analyzed through several techniques for characterization (Figures S2-S4), including X-ray diffractometer (XRD, Bruker New D8 Advance ECO), Fourier-transform infrared spectroscopy in attenuated total reflectance mode (FTIR-ATR, PerkinElmer Frontier universal ATR), thermogravimetric analysis (TGA, Q500, TA Instruments), dynamic light 
scattering (DLS, Brookhaven 90 plus), and scanning electron microscopy (SEM, EDX mics F + Hitachi Deben). Total $\mathrm{N}$ in all fertilizers was measured using an elemental analyzer (LECO CN-828, LECO Corporation, MI, US) according to the Dumas dry combustion method (Wright and Bailey 2001). After synthesis, nanoformulations were sonicated (VWR ultrasonic cleaner 97043-938) for $30 \mathrm{~min}$ at room temperature and then applied directly to leaves using a hand sprayer. All treatments were distributed in a completely randomized design $(n=4)$ under controlled temperature conditions, set at $20^{\circ} \mathrm{C}$ and verified using a data logger device (HT-HR TruTrack Data Logger for Humidity and Temperature, Intech Instruments). The photoperiod was adjusted to $16 / 8$ day-night hours using LED lamps (LED T8 Glass tube 18w, $6500 \mathrm{k}$ daylight, FSLT812 $18 \mathrm{~W}$ ). Both temperature and photoperiod were set in order to simulate spring-summer season conditions. Soil moisture was adjusted twice a week through gravimetric water balance, directly adding distilled water to the soil when required, to a target of $75 \%$ WFPS.

\subsection{Ammonia Volatilization Measurements}

Ammonia volatilization quantification was carried out using dynamic PVC chambers (Figure S1b), as previously described by Alfaro et al. (2018). Briefly, 28 chambers of $11 \mathrm{~cm}$ internal diameter and $10 \mathrm{~cm}$ height were used and placed on top of each lysimeter after $\mathrm{N}$ application. Each chamber had a transparent lid on top to allow the passage of light assuring plant photosynthesis. Using a vacuum pump, continuous airflow was circulated at $4 \mathrm{~L} \mathrm{~min}^{-1}$ as a carrier of volatilized $\mathrm{NH}_{3}$. Airflow was drawn to the system through two inlets and two outlets placed in each of the chambers, and flux was daily controlled with a rotameter (2-20 SCFH/1-10 LPM, LZT-08A01M-V, No. 1306 1803). Two flasks containing $100 \mathrm{~mL}$ of orthophosphoric acid $\left(\mathrm{H}_{3} \mathrm{PO}_{4}\right) 0.02 \mathrm{M}$ each were placed before airflow inlets as an acid trap and following airflow outlets to collect samples of volatilized $\mathrm{NH}_{3}$. A moisture trap between sample flasks and vacuum pump was also included to avoid condensation into the system. Acid traps and sample solutions were changed at $2 \mathrm{~h}, 6 \mathrm{~h}$, and then every $24 \mathrm{~h}$ during the first week and then every 2-3 days until day 21, with continuous $\mathrm{NH}_{3}$ accumulation in solution up to the respective sampling day. Samples were weighed and stored frozen $\left(-20^{\circ} \mathrm{C}\right)$ in $125-\mathrm{mL}$ plastic bottles until analysis for $\mathrm{N}_{-} \mathrm{NH}_{4}$ using automated colorimetry (SKALAR, SA 4000, Breda, the Netherlands), through reaction with sodium dichloroisocyanurate, sodium salicylate, and sodium nitroprusside to form indophenol dye (Searle 1984).

Ammonia emission rates ( $\mathrm{mg}$ of $\mathrm{N}-\mathrm{NH}_{3} \mathrm{~m}^{-2} \mathrm{~h}^{-1}$ ) for each sampling period were calculated following Eq. 1 (Misselbrook et al. 2005):
$N-\mathrm{NH}_{3}$ rate $=(\mathrm{CxV}) /(\mathrm{Axt})$

where $C$ is $\mathrm{N}-\mathrm{NH}_{4}$ concentration of the acid trap solution ( $\left.\mathrm{mg} \mathrm{L}^{-1}\right), V$ is the volume of acid trap solution (L), $A$ is the exposed surface area of the chamber $\left(\mathrm{m}^{-2}\right)$, and $t$ is the duration of the sampling period (h). The total emission corresponds to the sum of daily emissions collected during the experimental time period (21 days).

\subsection{Nitrous Oxide Emission Measurements}

Nitrous oxide emissions were quantified adapting the dynamic chambers (Figure S1b). At the end of each sampling period for $\mathrm{NH}_{3}$, airflow was stopped, and the vacuum pump disconnected, using the chamber in a static condition. All chamber inlets and outlets were sealed with plastic taps leaving only one outlet with a three-way stopcock connector. Through this connector, air samples $(30 \mathrm{~mL})$ were collected using a syringe at 0,30 , and $60 \mathrm{~min}$ and stored in $22-\mathrm{mL}$ glass vials. Air samples were sampled before $\mathrm{N}$ fertilization and at $2 \mathrm{~h}, 6 \mathrm{~h}$, and then every $24 \mathrm{~h}$ during the first week. Then, air sampling frequency continued every $2-3$ days for the following 2 weeks, and once a week until day 53. The concentration of $\mathrm{N}_{2} \mathrm{O}$ in the gas samples was determined using a gas chromatograph (Perkin Elmer ${ }^{\circledR}$ Precisely, Clarus 600 Model, Shelton, USA) fitted with a ${ }^{63} \mathrm{Ni}$ electron capture detector (ECD) and a Carboxen ${ }^{\mathrm{TM}} 1010$ PLOT column $(15 \mathrm{~m} \times 0.32 \mathrm{~mm}$ ID, Sigma-Aldrich Co. LLC., St. Louis, USA). The oven, injector, and ECD temperatures were operated at 60,260 , and $360^{\circ} \mathrm{C}$, respectively. The carrier gas was helium with a flow of $4 \mathrm{~mL} \mathrm{m^{-1 }}$. The minimum detectable flux for the methodology was $11 \mu \mathrm{g} \mathrm{N}-\mathrm{N}_{2} \mathrm{O} \mathrm{m}{ }^{-2} \mathrm{~h}^{-1}$.

The $\mathrm{N}_{2} \mathrm{O}$ fluxes were calculated from the slope of the linear increase or decrease of the three concentrations measured over the enclosure time, similarly to the procedure outlined by Saggar et al. (2004). Flux rates were expressed on an elemental weight basis as $\mathrm{mg} \mathrm{N}-\mathrm{N}_{2} \mathrm{O} \mathrm{m}^{-2} \mathrm{~h}^{-1}$. Flux rates were calculated and adjusted for air temperature, atmospheric pressure, and the ratio of chamber volume to surface area as follows in Eq. 2:

$N-N_{2}$ Orate $=(\Delta C / \Delta t) x(M / V m) x(V / A)$

where $\Delta C / \Delta t$ is the slope of the headspace concentration during the enclosure time $\left(\mathrm{ppm} \mathrm{h}^{-1}\right), M$ is the atomic weight of the gas ( 28 for $\mathrm{N}-\mathrm{N}_{2} \mathrm{O}, 2 \mathrm{~N}$ atoms in the $\mathrm{N}_{2} \mathrm{O}$ molecule), $V m$ is the pressure and temperature-corrected mole volume $\left(\mathrm{L} \mathrm{mol}^{-1}\right), V$ is the volume of the measuring chamber $\left(\mathrm{m}^{3}\right)$, and $A$ is the area of the measuring chamber $\left(\mathrm{m}^{2}\right)$. The fraction $V / A$ equals the height of the measuring chamber.

$V m=(R x T) / n \times P$ 
In Eq. 3, $R$ is the gas constant $0.08205 \mathrm{~atm} \mathrm{~L} \mathrm{~mol}^{-1} \mathrm{~K}^{-1}$, $T$ is the chamber temperature during the measurement (Kelvin), $n$ is equivalent to $1 \mathrm{~mol}$ of the gas, and $P$ is the air pressure at the experimental site. Air pressure inside the chamber was estimated from the height above sea level using a barometric equation. To calculate cumulative fluxes, daily fluxes were then added according to the measurement period before averaging across the four replicate chambers. Days without measurements were filled by linear interpolation.

\subsection{Net N Losses from Total N Applied}

Gaseous net $\mathrm{N}$ losses from total $\mathrm{N}$ applied were calculated from the difference between emissions from each $\mathrm{N}$ treatment and the control, divided by the applied $\mathrm{N}$ rate. Nitrogen losses were expressed as the percentage of total $\mathrm{N}$ applied for $\mathrm{NH}_{3}, \mathrm{~N}_{2} \mathrm{O}$, and total $\mathrm{N}$. Indirect $\mathrm{N}_{2} \mathrm{O}$ emissions were calculated for net total $\mathrm{N}$ losses in both experiments, according to the Intergovernmental Panel on Climate Change guidelines (IPCC 2006) using the default emission factor $\mathrm{EF}_{4}(1 \%)$ for volatilized $\mathrm{N}\left(\mathrm{N}-\mathrm{NH}_{3}\right)$.

\subsection{Additional Determinations}

\subsubsection{Soil Available N Concentration}

At the end of the experiment, lysimeters were dissembled, soil was thoroughly mixed, and a subsample was sieved $(2 \mathrm{~mm})$ and then use to estimate soil available $\mathrm{N}$ $\left(\mathrm{N}-\mathrm{NO}_{3}{ }^{-}\right.$plus $\mathrm{N}-\mathrm{NH}_{4}{ }^{+}$) following the methodology compiled by Sadzawka et al. (2006). Samples were analyzed using automated colorimetry (SKALAR, SA 4000, Breda, the Netherlands) after extraction with $2 \mathrm{M} \mathrm{KCl}$ solution. Final soil concentration was corrected by the respective soil water content, by air drying samples at $105^{\circ} \mathrm{C}$ for $24 \mathrm{~h}$ (Rowell 1997).

\subsubsection{Plant Yield and N Uptake}

Two harvests were carried out on days 32 and 74 after fertilizers application, once plants reached $25 \mathrm{~cm}$ height, on average, leaving a $5 \mathrm{~cm}$ of plant neck and leaves over soil surface, in each lysimeter to allow further regrowth. Dry mater concentration (\%) was determined by drying the clippings obtained at $60{ }^{\circ} \mathrm{C}$ for $24-48 \mathrm{~h}$ or until constant weight, according to Sadzawka et al. (2007). Yield $\left(\mathrm{g} \mathrm{DM} \mathrm{m}^{-2}\right)$ was calculated multiplying total fresh plant weight from each lysimeter by the dry matter concentration and then expressed as grams of dry matter yield per unit area. Nitrogen concentration in plant leaves (\%) was determined by the Kjeldahl digestion method (AOAC 2016) for each harvest and used to determine $\mathrm{N}$ uptake per treatment using the respective yield estimation.

\subsection{Statistical Analysis}

Rates and cumulative $\mathrm{NH}_{3}$ and $\mathrm{N}_{2} \mathrm{O}$ emissions, soil available $\mathrm{N}$ at the end of the experimental period, plant yield, $\mathrm{N}$ concentration in plant leaves, and $\mathrm{N}$ uptake were analyzed using JMP® 10.0.0. Mean statistical differences $(p<0.05)$ were estimated using ANOVA followed by Tukey-HSD test. For outliers detection, a robust Z-score method was conducted (Iglewicz and Hoaglin 1993). All data met the assumption of normality and homogeneity of variance.

\section{Results}

\subsection{Characterization of Nanoformulations}

The cross analysis of the structural characterization techniques (XRD and FT-IR) confirms the presence of nanostructures bound to urea, $\mathrm{NH}_{4}$, and $\mathrm{NO}_{3}$, detected by FT-IR peaks of bonds' vibrations of the molecules (see examples in Figures S2 and S3). The degree of functionalization determined by TGA obtained by the synthesis of Urea-F and $\mathrm{NH}_{4}-\mathrm{F}$ was $c .13 \%$ by weight with an irregular and slightly porous surface (see example in Figure $\mathrm{S} 4$ ). For $\mathrm{NO}_{3}-\mathrm{F}$, the TGA and the derivative thermogravimetric analysis (DTG) indicated an ion exchange capacity of c. $3.9 \mathrm{mmol} \mathrm{NO}_{3}$. Particle size in solution by DLS ranged from 121 to $195 \mathrm{~nm}$, after dissolution, sonication, and stirring.

\subsection{Ammonia Volatilization}

Cumulative $\mathrm{NH}_{3}$ emissions during the 21-day sampling period ranged from $101.4 \pm 19.5$ to $2,550.7 \pm 197.9 \mathrm{mg}$ $\mathrm{NH}_{3}-\mathrm{N} \mathrm{m}^{-2}$ for the different $\mathrm{N}$ treatments, being higher for $\mathrm{NH}_{4}-\mathrm{F}>$ Urea-d, Urea-F $>$ Urea-g, $\mathrm{NH}_{4} \mathrm{NO}_{3}$, and $\mathrm{NO}_{3}-\mathrm{F}$ (Table 1). For ammonium- and urea-based formulations, $\mathrm{NH}_{3}$ emissions were higher during the first $2 \mathrm{~h}$ after fertilizer application, contrasting to what was observed for nitrate-based treatments (Fig. 1a). On the other hand, $\mathrm{NH}_{4}-\mathrm{F}$ reached $826 \pm 62.0$ and $\mathrm{NO}_{3}-\mathrm{F}$ reached $2.0 \pm 0.3 \mathrm{mg} \mathrm{N}-\mathrm{NH}_{3}$ $\mathrm{m}^{-2} \mathrm{~h}^{-1}$ after $2 \mathrm{~h}$ of $\mathrm{N}$ application $(p<0.05)$, respectively. For all nitrate-based formulations, daily emission rates were low and similar to those of the control treatment over the 21 days of the evaluation period (Fig. 1a, $p>0.05$ ).

Greater emissions were observed with foliar ammonium-based nanoformulation compared to Urea-d and Urea-F ( $p<0.05$; Table 1), representing $c .51 \%, 22 \%$, and $19 \%$ of the applied $\mathrm{N}$, respectively. On the other hand, 
Table 1 Total cumulative $\mathrm{N}$ losses $\left(\mathrm{mg} \mathrm{N} \mathrm{m}^{-2}\right)$ during the sampling period for the different $\mathrm{N}$ treatments applied. Average value \pm standard error of the mean $(n=4)$

\begin{tabular}{|c|c|c|c|c|c|c|c|c|}
\hline \multirow[t]{2}{*}{ Treatments } & \multicolumn{4}{|c|}{ Total cumulative $\mathrm{N}$ losses $\left(\mathrm{mg} \mathrm{N} \mathrm{m}^{-2}\right)$} & \multicolumn{3}{|c|}{$\mathrm{N}$ loss from total $\mathrm{N}$ applied (\%) } & \multirow{2}{*}{$\begin{array}{l}\text { Indirect } \mathrm{N}-\mathrm{N}_{2} \mathrm{O} \\
\text { emissions }(\mathrm{mg} \mathrm{N} \\
\left.\mathrm{m}^{-2}\right) \\
\mathrm{N}-\mathrm{N}_{2} \mathrm{O}\end{array}$} \\
\hline & $\mathrm{N}-\mathrm{NH}_{3}$ & $\mathrm{~N}-\mathrm{N}_{2} \mathrm{O}$ & $\begin{array}{l}\text { Total gaseous } \\
\text { losses }\end{array}$ & Net total losses & $\mathrm{N}-\mathrm{NH}_{3}$ & $\mathrm{~N}-\mathrm{N}_{2} \mathrm{O}$ & Net total losses & \\
\hline Control & $23 \pm 4.2 \mathrm{~d}$ & $4 \pm 0.1 \mathrm{~d}$ & $27 \pm 4.3 \mathrm{~d}$ & NA & NA & NA & NA & NA \\
\hline Urea-g & $488 \pm 38.0 \mathrm{c}$ & $14 \pm 1.7 \mathrm{ab}$ & $503 \pm 37.4 \mathrm{c}$ & $476 \pm 37.7 \mathrm{c}$ & $9.3 \pm 0.8 \mathrm{c}$ & $0.21 \pm 0.03 \mathrm{ab}$ & $9.5 \pm 0.8 \mathrm{c}$ & $4.9 \pm 0.4 \mathrm{c}$ \\
\hline Urea-d & $1,110 \pm 77.1 b$ & $16 \pm 2.0 \mathrm{a}$ & $1,126 \pm 79.0 b$ & $1,100 \pm 77.4 b$ & $21.7 \pm 1.5 b$ & $0.25 \pm 0.04 \mathrm{a}$ & $22.0 \pm 1.6 \mathrm{~b}$ & $11.1 \pm 0.8 b$ \\
\hline $\mathrm{NH}_{4} \mathrm{NO}_{3}$ & $242 \pm 64.2 \mathrm{~cd}$ & $9 \pm 0.7 b c$ & $252 \pm 64.3 \mathrm{~cd}$ & $225 \pm 68.5 b$ & $4.4 \pm 1.4 \mathrm{c}$ & $0.11 \pm 0.02 b c$ & $4.5 \pm 1.47 \mathrm{c}$ & $2.4 \pm 0.6 \mathrm{c}$ \\
\hline $\mathrm{NO}_{3}-\mathrm{F}$ & $101 \pm 19.5 \mathrm{~cd}$ & $7 \pm 0.5 \mathrm{~cd}$ & $109 \pm 20.0 \mathrm{~cd}$ & $82 \pm 20.1 c$ & $1.6 \pm 0.4 \mathrm{c}$ & $0.07 \pm 0.01 \mathrm{c}$ & $1.6 \pm 0.4 \mathrm{c}$ & $1.0 \pm 0.2 \mathrm{c}$ \\
\hline Urea-F & $980 \pm 64.6 b$ & $10 \pm 1.0 \mathrm{bc}$ & $990 \pm 64.4 b$ & $963 \pm 58.7 b$ & $19.1 \pm 1.3 b$ & $0.12 \pm 0.02 b c$ & $19.3 \pm 1.3 b$ & $9.8 \pm 0.6 b$ \\
\hline $\mathrm{NH}_{4}-\mathrm{F}$ & $2,551 \pm 197.9 \mathrm{a}$ & $13 \pm 0.8 \mathrm{ab}$ & $2,564 \pm 198.3 a$ & $2,537 \pm 176.9 \mathrm{a}$ & $50.6 \pm 4.0 \mathrm{a}$ & $0.18 \pm 0.02 \mathrm{ab}$ & $50.7 \pm 4.0 \mathrm{a}$ & $25.5 \pm 2.0 \mathrm{a}$ \\
\hline
\end{tabular}

Different letters in columns indicate significant differences $(p<0.05)$, LS means comparison by Tukey HSD test, NA not applicable

Fig.1 Nitrogen emissions as a $\mathrm{mg} \mathrm{N}-\mathrm{NH}_{3} \mathrm{~m}^{-2} \mathrm{~h}^{-1}$ and $\mathbf{b}$ $\mathrm{mg} \mathrm{N}-\mathrm{N}_{2} \mathrm{O} \mathrm{m} \mathrm{m}^{-2} \mathrm{~h}^{-1}$ following the application of different foliar $\mathrm{N}$ formulations. Average values \pm standard error of the mean $(n=4)$

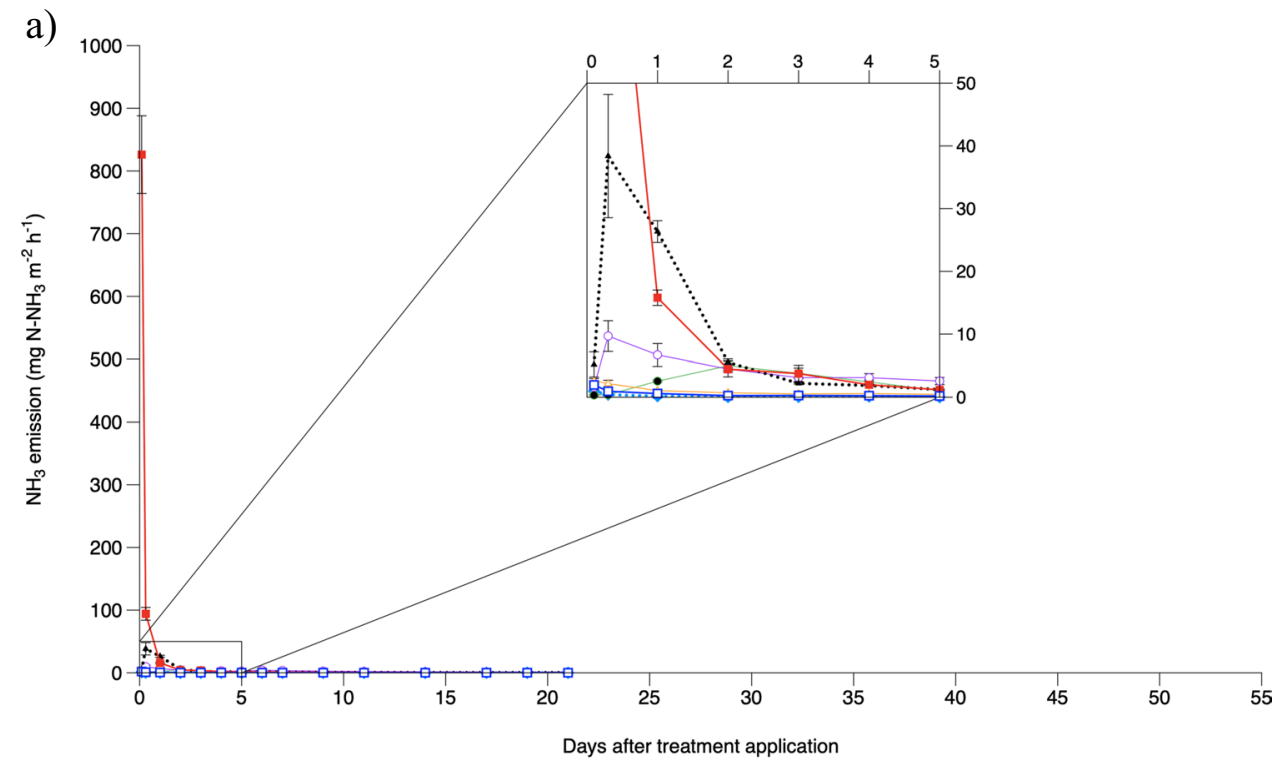

b)

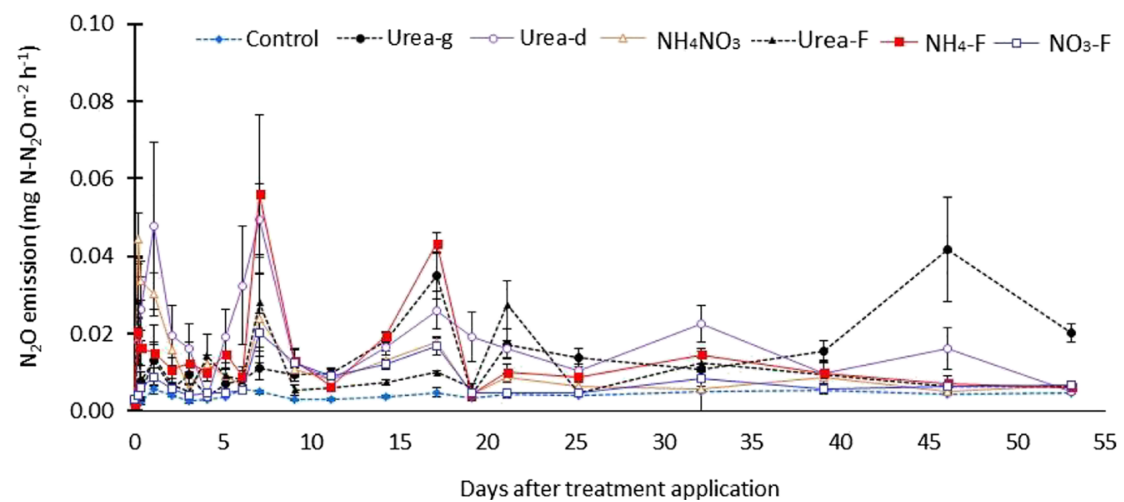

$\mathrm{NH}_{3}$ losses from $\mathrm{NH}_{4} \mathrm{NO}_{3}$ and $\mathrm{NO}_{3}-\mathrm{F}$ were low, with emissions similar to those observed under control conditions $(p>0.05$ ), equivalent to $<5 \%$ of total cumulative loss. Additionally, $\mathrm{NH}_{3}$ volatilization was 25 and 111-fold greater with $\mathrm{NH}_{4}-\mathrm{F}$ (largest $\mathrm{N}$ loss) than $\mathrm{NO}_{3}-\mathrm{F}$ and control treatments (lowest $\mathrm{N}$ loss), respectively. 


\subsection{Nitrous Oxide Emissions}

Cumulative $\mathrm{N}_{2} \mathrm{O}$ losses during the experimental period were greater in the urea treatments, either as granular or foliar fertilizer, reaching up to $31 \mathrm{mg} \mathrm{N} \mathrm{m}^{-2}$ after $\mathrm{N}$ application (Table 1), with no differences between soil (granular) and foliar applications $(p>0.05)$. The lowest emissions were registered in the control treatment $\left(3.8 \mathrm{mg} \mathrm{N} \mathrm{m}^{-2}, p<0.05\right)$. The use of $\mathrm{NH}_{4} \mathrm{NO}_{3}$ as foliar fertilizer significantly reduced $\mathrm{N}_{2} \mathrm{O}$ losses by $42 \%$ in relation to Urea-d. The use of nanoformulations significantly reduced $\mathrm{N}_{2} \mathrm{O}$ losses when applied as $\mathrm{NO}_{3}$ or urea, by $56 \%$ and $41 \%$, respectively in relation to Urea-d $(p<0.05)$.

Losses of $\mathrm{N}_{2} \mathrm{O}$ were distributed along the sampling period and only reached similar fluxes to those of the control treatment after day 35, except for the Urea-g treatment (Fig. 1b). Emissions were significantly higher in the first 3 weeks after the fertilizer application $\left(2.2 \mathrm{mg} \mathrm{N} \mathrm{m}^{-2}\right.$, on average), in comparison to the emissions during the rest of the evaluation period $\left(0.8 \mathrm{mg} \mathrm{N} \mathrm{m}^{-2}\right.$, on average). The $\mathrm{NH}_{4} \mathrm{NO}_{3}$ and Urea-d emissions started immediately after application, while granular urea emissions started 1 week after application. Nanoformulations had lower initial emission rates, compared to conventional fertilizers, either applied to the soil or plants leaves.

Direct $\mathrm{N}_{2} \mathrm{O}$ losses were low compared to $\mathrm{NH}_{3}$ losses $(<5 \%$ expressed as net total, and $1.8 \% \pm 0.5$, on average, Tables 1 and S3). Indirect $\mathrm{N}_{2} \mathrm{O}$ emissions were high in ureabased formulations (Urea-d, Urea-F y Urea-g) and in $\mathrm{NH}_{4}-\mathrm{F}$ treatment, ranging from $4.9 \pm 0.4$ to $25.5 \pm 2.0 \mathrm{mg} \mathrm{N} \mathrm{m}^{-2}$ $(p<0.05$, Table $\mathrm{S} 3)$. From all $\mathrm{N}$ treatments, the lowest indirect losses were observed in $\mathrm{NO}_{3}-\mathrm{F}$ and $\mathrm{NH}_{4} \mathrm{NO}_{3}$ formulations ( $p>0.05$; Table 1). Thus, indirect $\mathrm{N}_{2} \mathrm{O}$ losses were 0.3 $\left(\mathrm{NO}_{3}-\mathrm{F}\right.$ treatment) to $2.8\left(\mathrm{NH}_{4}-\mathrm{F}\right.$ treatment $)$ times greater than those directly measured during the experiment.

Net losses were similar to $\mathrm{NH}_{3}$ emissions, varying from

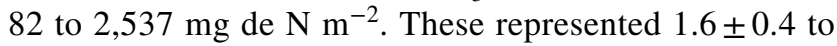
$50.7 \pm 4.0 \%$ of the total $\mathrm{N}$ applied. Nitrogen loss as $\mathrm{N}_{2} \mathrm{O}$ was low and did not exceed $0.2 \%$ of $\mathrm{N}$ applied.

\subsection{Soil Available $\mathrm{N}$ and Yield}

No significant treatments effect was observed on final soil available $\mathrm{N}$ concentration ( $p>0.05$; Table 2$)$, which ranged between 22 and $30 \mathrm{mg} \mathrm{kg}^{-1} \mathrm{ds}$, although these values were higher than the initial soil concentration $\left(10.8 \pm 1.3 \mathrm{mg} \mathrm{kg}^{-1}\right.$ ds, Table S1).

Treatments did not affect plant yield or $\mathrm{N}$ foliar concentration at each harvest or the total cumulative value ( $p>0.05$; Table 2). Plant yield varied between 271 and $451 \mathrm{~g}$ DM $\mathrm{m}^{-2}$ for the experimental period, while $\mathrm{N}$ foliar concentra-

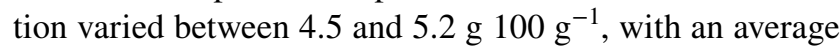

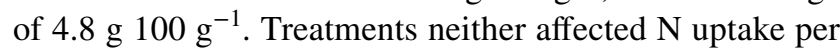
harvest or overall values $(p>0.05)$, varying between 13 and $22 \mathrm{~g} \mathrm{~N} \mathrm{~m}^{-2}$.

\section{Discussion}

The XRD and FT-IR analysis of $\mathrm{NO}_{3}$-F showed similar patterns to those reported by Ureña-Amate et al. (2011) and Jobbágy and Iyi (2010). For Urea-F, two phases were observed showing urea bonded to the nanostructure (Figure S2), as characteristic of these materials (Kottegoda et al. 2017). On the other hand, FT-IR analysis showed a consistent pattern for these molecules (Figure S2) as previously reported by Bianco et al. (2009). The TGA analysis showed three decomposition stages in the nanoformulations, similar to those reported by Kameda et al. (2010) and Bianco et al. (2009). Particle size analysis according to DLS and SEM micrographs (Figure S3) showed that the dimension of the nanostructures in all the nanoformulations was within the range reported for other nanomaterials as in Meier et al. (2020) and Bianco et al. (2009).

Volatilization of $\mathrm{NH}_{3}$ was found to be the main pathway of $\mathrm{N}$ loss in agreement with previous results in similar volcanic soils (Alfaro et al. 2018; Salazar et al. 2014) and other soil types elsewhere (Pan et al. 2016). In the present study, $\mathrm{NH}_{3}$ losses were directly affected by the $\mathrm{N}$ form in the

Table 2 Treatments effect on final soil available $\mathrm{N}$ concentration $\left(\mathrm{mg} \mathrm{kg}^{-1} \mathrm{ds}\right)$, overall plant yield $\left(\mathrm{g} \mathrm{DM} \mathrm{m}^{-2}\right)$, overall $\mathrm{N}$ concentration $(\mathrm{g}$ $100 \mathrm{~g}^{-1}$ ), and overall $\mathrm{N}$ plant uptake $\left(\mathrm{g} \mathrm{N} \mathrm{m}^{-2}\right), n=4, \pm$ standard error of the mean

\begin{tabular}{|c|c|c|c|c|c|c|c|c|c|}
\hline \multirow[t]{2}{*}{ Parameters } & \multirow[t]{2}{*}{ Unit } & \multicolumn{7}{|l|}{ Treatments } & \multirow[t]{2}{*}{$p$-value } \\
\hline & & Control & Urea-g & Urea-d & $\mathrm{NH}_{4} \mathrm{NO}_{3}$ & $\mathrm{NO}_{3}-\mathrm{F}$ & Urea-F & $\mathrm{NH}_{4}-\mathrm{F}$ & \\
\hline \multicolumn{10}{|l|}{ Soil } \\
\hline Available N & $\mathrm{mg} \mathrm{N} \mathrm{kg}{ }^{-1} \mathrm{ds}$ & $26.8 \pm 2.7$ & $30.3 \pm 4.5$ & $26.2 \pm 3.0$ & $21.6 \pm 6.3$ & $24.5 \pm 3.9$ & $25.7 \pm 5.4$ & $21.8 \pm 4$ & 60.834 \\
\hline \multicolumn{10}{|l|}{ Plant } \\
\hline Dry matter yield & $\mathrm{g} \mathrm{DM} \mathrm{m}^{-2}$ & $422 \pm 38.6$ & $360 \pm 63.6$ & $271 \pm 45.9$ & $329 \pm 44.3$ & $451 \pm 70.5$ & $417 \pm 95.0$ & $432 \pm 61.0$ & 0.395 \\
\hline $\mathrm{N}$ concentration & $\mathrm{g} 100 \mathrm{~g}^{-1}$ & $4.7 \pm 0.09$ & $4.8 \pm 0.1$ & $4.9 \pm 0.1$ & $4.9 \pm 0.1$ & $4.8 \pm 0.04$ & $4.8 \pm 0.1$ & $4.8 \pm 0$ & 10.703 \\
\hline Total N uptake & $\mathrm{g} \mathrm{N} \mathrm{m}^{-2}$ & $19.8 \pm 1.56$ & $17.4 \pm 3.0$ & $13.5 \pm 2.1$ & $16.4 \pm 2.1$ & $21.7 \pm 3.5$ & $19.9 \pm 4.2$ & $20.8 \pm 3$ & 00.449 \\
\hline
\end{tabular}

Different letters in columns indicate significant differences $(p<0.05)$ 
fertilizer source, with high emissions after the application of $\mathrm{NH}_{4}-\mathrm{F}$, compared to the urea-based formulations. This can be associated to the rapid release of $\mathrm{NH}_{4}$ in an aqueous solution. In fact, more than $80 \%$ of the total $\mathrm{N}$ was released when $\mathrm{NH}_{4}-\mathrm{F}$ was dissolved in water (Table S5) after 2-h reaction time. This suggests a fast equilibrium between $\mathrm{NH}_{4}$ and $\mathrm{NH}_{3}$ in liquid solutions, in agreement with Sigurdarson et al. (2018). Losses were low in the nitrate-based fertilizers, as expected given the reduced potential for $\mathrm{N}-\mathrm{NH}_{3}$ formation, according to previous studies reported by Pan et al. (2016) with $\mathrm{NH}_{4} \mathrm{NO}_{3}$ in different agricultural systems. There is a lack of information on $\mathrm{N}$ gaseous emissions, particularly of concurrent measurements of $\mathrm{NH}_{3}$ and $\mathrm{N}_{2} \mathrm{O}$, after foliar application of nanoformulations (Mejías et al. 2021) so that no direct comparison to similar formulations can be presented.

Ammonia losses occurred immediately after $\mathrm{N}$ application, especially in ammonium- and urea-based nanoformulations, where on average volatilization rates were equivalent to $65 \%, 72 \%$, and $82 \%$ at $2 \mathrm{~h}, 6 \mathrm{~h}$, and $24 \mathrm{~h}$, respectively. For Urea-g, $\mathrm{NH}_{3}$ loss occurred after those from dissolved formulations, with high emissions $48 \mathrm{~h}$ after $\mathrm{N}$ fertilization. This delay effect could be related to the time required for the urease enzyme to hydrolyze urea, as reported previously by Dawar et al. (2011). Additionally, the study carried out by Torello and Wehner (1983) in Kentucky bluegrass turf (Poa pratensis $\mathrm{L}$.) showed that on a dry weight basis, urease activity was 18 to 30 times higher from turfgrass clippings than in soil, which can explain the higher losses observed in foliar versus granular formulation application. Also, the surface area in foliar application is larger than granular formulations, which can exacerbate $\mathrm{NH}_{3}$ loss.

The use of foliar $\mathrm{N}$ application has been previously foreseen to reduce $\mathrm{N}_{2} \mathrm{O}$ emissions (Freney 1997). Foliar $\mathrm{N}$ application would allow to bypass soil $\mathrm{N}$ cycle, significantly reducing $\mathrm{N}_{2} \mathrm{O}$ emissions. Nevertheless, emissions still occur as $\mathrm{N}_{2} \mathrm{O}$ dissolved in the soil solution can be taken up by plant roots and eventually being translocated through transpiration stream and released through open stomata (Ferch and Römheld 2001; Pihlatie et al. 2005), being transported to the leaf through the xylem along with the upward movement of water (Borah and Baruah 2016; Bowatte et al. 2014; Pihlatie et al. 2005). In this case, the leaf area, stomatal density, and xylem vessel size can be associated with $\mathrm{N}_{2} \mathrm{O}$ emissions (Bordoloi and Baruah 2017).

The use of $\mathrm{NH}_{4} \mathrm{NO}_{3}$ as $\mathrm{N}$ source with only a fraction of the $\mathrm{N}$ applied as $\mathrm{NO}_{3}$, resulted in lower $\mathrm{N}_{2} \mathrm{O}$ emissions, suggesting this source of $\mathrm{N}$ as a potential alternative to reduce $\mathrm{N}_{2} \mathrm{O}$ losses. However, $\mathrm{N}_{2} \mathrm{O}$ emissions from $\mathrm{NH}_{4}$-based formulations did not differ from those of conventional fertilizers. As indicated previously, volcanic ash soils can significantly adsorbed $\mathrm{NH}_{4}{ }^{+}$thus also reducing $\mathrm{NO}_{3}{ }^{-}$availability (Cardenas et al. 2013; Huygens et al. 2007) and denitrification losses.
According to our results, total cumulative $\mathrm{NH}_{3}$ volatilization resulted in 14 to 196 times greater losses than those as $\mathrm{N}_{2} \mathrm{O}$ considering the different fertilizer treatments, with the highest values in $\mathrm{NH}_{4}-\mathrm{F}$, Urea-F, and Urea-d treatments (Table 1). As $\mathrm{NH}_{3}$ has been recognized as $\mathrm{N}_{2} \mathrm{O}$ precursor (Erisman et al. 2007), in the current experiment, indirect $\mathrm{N}_{2} \mathrm{O}$ emissions from $\mathrm{NH}_{3}$ volatilization varied between 1.0 and $25.5 \mathrm{mg} \mathrm{N}-\mathrm{N}_{2} \mathrm{O} \mathrm{m}^{-2}$. Therefore, in the $\mathrm{NH}_{4}-\mathrm{F}$ treatment, indirect $\mathrm{N}_{2} \mathrm{O}$ losses due to $\mathrm{NH}_{3}$ volatilization were more relevant than direct $\mathrm{N}_{2} \mathrm{O}$ losses. This has been previously observed in concurrent measurements carried out after the application of $\mathrm{N}$ conventional fertilizers (Alfaro et al. 2018).

Although no significant effect on yield or $\mathrm{N}$ uptake was observed under controlled experimental conditions, this could be related to a masking effect of soil organic matter mineralization given the experimental set up with optimum conditions of temperature and soil moisture for microbial activity compared to field conditions, which resulted in an increase of soil available $\mathrm{N}$ of 2.4 times the initial value, with no significant differences between treatments. Soil organic matter mineralization in this Andisol has been previously described as a relevant source of $\mathrm{N}$ input in grassland systems, with contributions from c. 300 (Alfaro et al. 2009; Martínez-Lagos et al. 2015) up to $c .900 \mathrm{~kg} \mathrm{~N}^{-1}$ year $^{-1}$ in overfertilized sites (Lobos et al. 2016). This most likely resulted in the high $\mathrm{N}$ foliar concentrations, in agreement with results of pasture characterization in volcanic soils of southern Chile (Anrique 2014; Lobos et al. 2016; Pulido et al. 2010) and similar yield among treatments.

Our results showed that, high gaseous $\mathrm{N}$ losses were observed on ammonium- and urea-based formulations given the rapid formation of $\mathrm{NH}_{4}$ (Table S5) in these materials as discussed previously. In this context, future foliar nanofertilizers would benefit from considering the use of urease inhibitors (e.g., NBPT), as in granular urea fertilizers. The incorporation of inhibitors have shown to be effective in reducing $\mathrm{NH}_{3}$ volatilization from pastures and crops (Pan et al. 2016; Silva et al. 2017). Inhibitors can have an important effect especially on the first days following $\mathrm{N}$ application, where according to our results most of the $\mathrm{NH}_{3}$ losses were observed for ammonium and urea base formulations. Other alternatives may consider foliar nanoformulations with low $\mathrm{pH}$, in order to stabilize $\mathrm{NH}_{4}{ }^{+}$in the molecule, optimizing $\mathrm{N}$ absorption and potentially reducing environmental losses, in agreement with results showed by Dawar et al. (2011).

Our results indicate that further studies are required to fully understand the processes involved, the synergies, and swapping effects when using novel nanoformulations. As a result, the cost-benefit analysis of the use of these materials in grasslands is still uncertain. Additionally, potential implications for the agri-food chain under field conditions should be tested, considering the role of environmental conditions 
such as intense rainfall after application and the potential residues in plant, relevant for grazing animals' intake.

\section{Conclusions}

Greater losses were observed in urea-based formulations, due to ammonia volatilization, which represented between 2 and $51 \%$ of the $\mathrm{N}$ applied, which mainly occurred immediately after $\mathrm{N}$ application due to a rapid $\mathrm{NH}_{4}$ initial release and fast $\mathrm{NH}_{3}$ and $\mathrm{NH}_{4}$ equilibrium in water solutions.

Direct nitrous oxide losses were low varying between 0.07 and $0.25 \% \mathrm{~N}$ applied, which represented less than 5\% of the total net $\mathrm{N}$ losses. Nitrous oxide emissions were significantly higher in the first 3 weeks after the fertilizer application ( $2.2 \mathrm{~m} \mathrm{~N} \mathrm{~m}^{-2}$, on average), in comparison to emissions in the rest of the evaluation period. Due to the high ammonia losses obtained in all treatments, indirect nitrous oxide losses were 0.3 to 2.8 times greater than those directly measured in the experiment.

Ammonium-based nanoformulations require further physical and/or chemical improvements, to reduce $\mathrm{N}$ losses. These options represent an opportunity for the development of foliar fertilizers for permanent grasslands, focusing on reducing $\mathrm{N}$ rates applied given the intrinsic characteristics of nanoformulations. Further studies should include field evaluations, cost-benefit analyses, and potential impacts in the agri-food chain.

Supplementary Information The online version contains supplementary material available at https://doi.org/10.1007/s42729-022-00769-0.

Acknowledgements Thank you to Ecocompatible Polymeric Materials Laboratory (LMPE, Italy) for the physic-chemical characterization of nanomolecules and advise on nanotechnology matters, and to technical staff who collaborated in the execution of laboratory and fieldwork.

Funding This work was supported by ANID/CONICYT, FONDECYT grant 1180775.

\section{Declarations}

Competing Interest The authors declare no competing interests.

Open Access This article is licensed under a Creative Commons Attribution 4.0 International License, which permits use, sharing, adaptation, distribution and reproduction in any medium or format, as long as you give appropriate credit to the original author(s) and the source, provide a link to the Creative Commons licence, and indicate if changes were made. The images or other third party material in this article are included in the article's Creative Commons licence, unless indicated otherwise in a credit line to the material. If material is not included in the article's Creative Commons licence and your intended use is not permitted by statutory regulation or exceeds the permitted use, you will need to obtain permission directly from the copyright holder. To view a copy of this licence, visit http://creativecommons.org/licenses/by/4.0/.

\section{References}

Adisa IO, Pullagurala VLR, Peralta-Videa JR, Dimkpa CO, Elmer WH, Gardea-Torresdey JL, White JC (2019) Recent advances in nanoenabled fertilizers and pesticides: a critical review of mechanisms of action. Environ Sci Nano 6:2002-2030. https://doi.org/10.1039/ C9EN00265K

Agrahari S, Dubey A (2020) Nanoparticles in plant growth and development. pp 9-37

Alfaro M, Salazar F (2005) Ganadería y Contaminación Difusa, Implicancias para el Sur de Chile. Agric Téc 65:330-340. https://doi.org/10.4067/S0365-28072005000300012(Spanish)

Alfaro M, Salazar F, Oenema O, Iraira S, Teuber N, Ramirez L, Villarroel D (2009) Balances de nutrientes en sistemas de producción de carne del sur de chile y sus implicancias para el medioambiente. Rev Cienc Suelo Nutr Veg 9:40-54. https://doi. org/10.4067/S0718-27912009000100004(Spanish)

Alfaro M, Salazar F, Hube S, Ramírez L, MaS M (2018) Ammonia and nitrous oxide emissions as affected by nitrification and urease inhibitors. J Soil Sci Plant Nutr 18:479-486. https://doi.org/ 10.4067/S0718-95162018005001501

Aneja VP, Schlesinger WH, Erisman JW (2009) Effects of agriculture upon the air quality and climate: research, policy, and regulations. Environ Sci Technol 43:4234-4240. https://doi.org/10. 1021/es8024403

Anrique R (2014) Composición de alimentos para el ganado bovino. 4 ed. INIA, Valdivia, Chile (Spanish)

AOAC (2016) Official methods of analysis of AOAC INTERNATIONAL, 20th edn. Association of Official Analytical Chemists Washington, DC

Benício LP, Constantino V, Pinto F, Vergutz L, Tronto J, Costa L (2016) Layered double hydroxides: new technology in phosphate fertilizers based on nanostructured materials. ACS Sustain Chem Eng 5:. https://doi.org/10.1021/acssuschemeng.6b01784

Bianco A, Cacciotti I, Lombardi M, Montanaro L (2009) Si-substituted hydroxyapatite nanopowders: synthesis, thermal stability and sinterability. Mater Res Bull 44:345-354. https://doi.org/ 10.1016/j.materresbull.2008.05.013

Blennerhassett J, Quin B, Zaman M, Ramakrishnan C (2006) The potential for increasing nitrogen responses using Agrotaintreated urea. Proc N Z Grassl Assoc 68:297-301. https://doi. org/10.33584/jnzg.2006.68.2602

Borah L, Baruah KK (2016) Nitrous oxide emission and mitigation from wheat agriculture: association of physiological and anatomical characteristics of wheat genotypes. Environ Sci Pollut Res 23:709-721. https://doi.org/10.1007/s11356-015-5299-4

Bordoloi N, Baruah KK (2017) Effect of foliar application of plant growth regulators on nitrous oxide $\left(\mathrm{N}_{2} \mathrm{O}\right)$ emission and grain yield in wheat. Environ Sci Pollut Res 24:10481-10492. https:// doi.org/10.1007/s11356-017-8616-2

Bowatte S, Newton PC, Theobald P, Brock S, Hunt C, Lieffering M, Sevier S, Gebbie S, Luo D (2014) Emissions of nitrous oxide from the leaves of grasses. Plant Soil 374:275-283. https://doi. org/10.1007/s11104-013-1879-6

Cameron KC, Di HJ, Moir JL (2013) Nitrogen losses from the soil/ plant system: a review. Ann Appl Biol 162:145-173. https://doi. org/10.1111/aab.12014

Cardenas LM, Hatch DJ, Scholefield D, Jhurreea D, Clark IM, Hirsch PR, Salazar F, Rao-Ravella S, Alfaro M (2013) Potential mineralization and nitrification in volcanic grassland soils in Chile. Soil Sci Plant Nutr 59:380-391. https://doi.org/10.1080/00380 768.2013.789395

Cayuela ML, Aguilera E, Sanz-Cobena A, et al (2016) Direct nitrous oxide emissions in Mediterranean climate cropping systems: emission factors based on a meta-analysis of available 
measurement data. Agric Ecosyst Environ 238:. https://doi.org/ 10.1016/j.agee.2016.10.006

Chhowalla M (2017) Slow release nanofertilizers for bumper crops. ACS Cent Sci 3:. https://doi.org/10.1021/acscentsci.7b00091

CIREN (2003) Descripciones de suelos, materiales y símbolos. Estudio agrológico X Región. Tomo II. Centro de Información de Recursos Naturales (CIREN), Santiago, Chile. (Spanish)

Dawar K, Zaman M, Rowarth J, Blennerhassett J, Turnbull M (2011) Urea hydrolysis and lateral and vertical movement in the soil: effects of urease inhibitor and irrigation. Biol Fertil Soils 47:139-146. https://doi.org/10.1007/s00374-010-0515-3

de Klein C, Monaghan R, Alfaro M, Gourley C, Oenema O, Powell $M$ (2017) Nitrogen performance indicators for dairy production systems. Soil Res 55:. https://doi.org/10.1071/SR16349

Dhir B (2021) Nanofertilizers and Their Applications. In: Kumar R, Kumar R, Kaur G (eds) New frontiers of nanomaterials in environmental science. Springer Singapore, Singapore, pp 229-241

Dimkpa CO, Fugice J, Singh U, Lewis TD (2020) Development of fertilizers for enhanced nitrogen use efficiency - Trends and perspectives. Sci Total Environ 731:139113. https://doi.org/10. 1016/j.scitotenv.2020.139113

Driver JG, Owen RE, Makanyire T, Lake JA, McGregor J, Styring P (2019) Blue urea: fertilizer with reduced environmental impact. Front Energy Res 7:88. https://doi.org/10.3389/fenrg.2019.00088

Erisman JW, Bleeker A, Galloway J (1987) Reduced nitrogen in ecology and the environment. Environ Pollut Barking Essex 1987. Environ Pollut Barking Essex 150:140-149. https://doi.org/10. 1016/j.envpol.2007.06.033

Ferch N, Römheld V (2001) Release of water-dissolved nitrous oxide by plants: does the transpiration water flow contribute to the emission of dissolved $\mathrm{N}_{2} \mathrm{O}$ by sunflower? In: Plant nutrition. Springer, pp 228-229

Freney J (1997) Emission of nitrous oxide from soils used for agriculture. Nutr Cycl Agroecosystems 49:1-6. https://doi.org/10. 1023/A: 1009702832489

Hong J, Wang C, Wagner DC, Gardea-Torresdey JL, He F, Rico CM (2021) Foliar application of nanoparticles: mechanisms of absorption, transfer, and multiple impacts. Environ Sci Nano 8:11961210. https://doi.org/10.1039/D0EN01129K

Hube S, Alfaro MA, Scheer C, Brunk C, Ramírez L, Rowlings D, Grace P (2017) Effect of nitrification and urease inhibitors on nitrous oxide and methane emissions from an oat crop in a volcanic ash soil. Quantif Mitig Greenh Gas Emiss Mediterr Crop Syst 238:4654. https://doi.org/10.1016/j.agee.2016.06.040

Huygens D, Rütting T, Boeckx P, Cleemput O, Godoy R, Müller C (2007) Soil nitrogen conservation mechanisms in a pristine south Chilean Nothofagus forest ecosystem. Soil Biol Biochem 39:2448-2458. https://doi.org/10.1016/j.soilbio.2007.04.013

Iglewicz B, Hoaglin D (1993) The ASQC basic references in quality control: statistical techniques. In: Mykytka, E.F., Eds., How to Detect and Handle Outliers. In: Press AQ (ed) American Society for Quality Control. Quality Press, Milwaukee, p 85

IPCC (2006) Guidelines for National Greenhouse Gas Inventories, Prepared by the National Greenhouse Gas Inventories Programme. IGES, Japan

IPCC (2014a) Core Writing Team. In: Pachauri RK, Allen MR, Barros VR, Broome J, Cramer W, Christ R, Church JA, Clarke L, Dahe Q, Dasgupta P (eds) Climate change 2014: synthesis Report. Contribution of Working Groups I, II and III to the Fifth Assessment Report of the Intergovernmental Panel on Climate change. Intergovernmental Panel on Climate Change, Geneva, Switzerland, $\mathrm{p} 151$

IPCC (2014b) Summary for Policymakers. In: Edenhofer O, PichsMadruga R, Sokona Y, et al. (eds) Climate Change 2014: Mitigation of Climate Change. Contribution of Working Group III to the Fifth Assessment Report of the Intergovernmental Panel on
Climate Change. Intergovernmental Panel on Climate Change, Cambridge University Press, Cambridge, United Kingdom and New York, NY, USA.

Jobbágy M, Iyi N (2010) Interplay of charge density and relative humidity on the structure of nitrate layered double hydroxides. J Phys Chem C 114:18153-18158. https://doi.org/10.1021/jp107 8778

Kameda T, Fubasami Y, Uchiyama N, Yoshioka T (2010) Elimination behavior of nitrogen oxides from a $\mathrm{NO}_{3}{ }^{-}$-intercalated $\mathrm{Mg}-\mathrm{Al}$ layered double hydroxide during thermal decomposition. Thermochim Acta 499:106-110

Kottegoda N, Sandaruwan C, Priyadarshana G, Siriwardhana A, Rathnayake UA, Berugoda Arachchige DM, Kumarasinghe AR, Dahanayake D, Karunaratne V, Amaratunga GAJ (2017) Ureahydroxyapatite nanohybrids for slow release of nitrogen. ACS Nano 11:1214-1221. https://doi.org/10.1021/acsnano.6b07781

Krol D, Forrestal P, Wall D, Lanigan G, Sanz-Gomez J, Richards K (2020) Nitrogen fertilisers with urease inhibitors reduce nitrous oxide and ammonia losses, while retaining yield in temperate grassland. Sci Total Environ 725:138329. https://doi.org/10. 1016/j.scitotenv.2020.138329

Leip A, Billen G, Garnier J, Grizzetti B, Lassaletta L, Reis S, Simpson D, Sutton M, Vries W, Weiss F, Westhoek H (2015) Impacts of European livestock production: nitrogen, sulphur, phosphorus and greenhouse gas emissions, land-use, water eutrophication and biodiversity. Environ Res Lett 10:115004. https://doi.org/ 10.1088/1748-9326/10/11/115004

Liu H, Baldwin C, Totten FW, McCarty LB (2008) Foliar fertilization for turfgrasses. Acta Hortic 783:323-332. https://doi.org/ 10.17660/ActaHortic.2008.783.34

Lobos I, Alfaro M, Martinez-Lagos J (2016) Soil nitrogen contribution to grasslands and its implication for nitrogen use efficiency. J Soil Sci Plant Nutr 16:310-322. https://doi.org/10. 4067/S0718-95162016005000027

Martínez-Lagos J, Salazar F, Alfaro M, Rosas M, Macías F (2015) Nitrogen mineralization in a silandic andosol fertilized with dairy slurry and urea. J Soil Sci Plant Nutr 15:60-75. https:// doi.org/10.4067/S0718-95162015005000006

Matheyarasu R, Seshadri B, Bolan NS, Naidu R (2016) Assessment of nitrogen losses through nitrous oxide from abattoir wastewater-irrigated soils. Environ Sci Pollut Res 23:22633-22646. https://doi.org/10.1007/s11356-016-7438-y

Meier S, Moore F, Morales A, González M-E, Seguel A, MeriñoGergichevich C, Rubilar O, Cumming J, Aponte H, Alarcón D, Mejías J (2020) Synthesis of calcium borate nanoparticles and its use as a potential foliar fertilizer in lettuce (Lactuca sativa) and zucchini (Cucurbita pepo). Plant Physiol Biochem 151:673-680. https://doi.org/10.1016/j.plaphy.2020.04.025

Mejías JH, Salazar F, Pérez Amaro L, Hube S, Rodriguez M, Alfaro M (2021) Nanofertilizers: a cutting-edge approach to increase nitrogen use efficiency in grasslands. Front Environ Sci 9:52. https://doi.org/10.3389/fenvs.2021.635114

Misselbrook TH, Powell JM, Broderick GA, Grabber JH (2005) Dietary manipulation in dairy cattle: laboratory experiments to assess the influence on ammonia emissions. J Dairy Sci 88:1765-1777. https://doi.org/10.3168/jds.S0022-0302(05) $72851-4$

MMA (2020) Cuarto Informe Bienal de Actualización de Chile sobre Cambio Climático, 4IBA. Santiago, Chile, p 445

Mora ML, Cartes P, Ramos P, Salazar M, Rolando D (2007) Movement of $\mathrm{NO}_{3}^{-}-\mathrm{N}$ and $\mathrm{NH}_{4}^{+}-\mathrm{N}$ in an Andisol and its influence on ryegrass production in a short-term study. Rev Cienc Suelo Nutr Veg 7:. https://doi.org/10.4067/S0718-27912007000200005

Oenema O, de Klein C, Alfaro M (2014) Intensification of grassland and forage use: driving forces and constraints. Crop Pasture Sci 65:524-537. https://doi.org/10.1071/CP14001 
Pacheco D, Waghorn G (2008) Dietary nitrogen-definitions, digestion, excretion and consequences of excess for grazing ruminants. pp $107-116$

Pan B, Mosier A, Chen D, Lam SK, Luo Y (2016) Ammonia volatilization from synthetic fertilizers and its mitigation strategies: a global synthesis. Agric Ecosyst Environ 232:283-289. https://doi.org/10. 1016/j.agee.2016.08.019

Pihlatie M, Ambus P, Rinne J, Pilegaard K, Vesala T (2005) Plantmediated nitrous oxide emissions from beech (Fagus sylvatica) leaves. New Phytol 168:93-98. https://doi.org/10.1111/j.14698137.2005.01542.x

Preetha PS, Balakrishnan N (2017) A review of nano fertilizers and their use and functions in soil. Int J Curr Microbiol Appl Sci 6:3117-3133. https://doi.org/10.20546/ijcmas.2017.612.364

Pulido R, Muñoz R, Jara C, Balocchi O, Smulders J, Wittwer F, Orellana P, O'Donovan M (2010) The effect of pasture allowance and concentrate supplementation type on milk production performance and dry matter intake of autumn-calving dairy cows in early lactation. Livest Sci 132:119-125. https://doi.org/10.1016/j. livsci.2010.05.010

Quin B, Gilligham AG, Baird D, Spilsbury S, Gray M (2015) A comparison under grazing of pasture production, pasture $\mathrm{N}$ content and soil mineral $\mathrm{N}$ levels between granular urea and $\mathrm{ONEsystem}(\mathrm{R})$ on two contrasting dairy farms in New Zealand. J N Z Grassl 77:259-267. https://doi.org/10.33584/jnzg.2015.77.462

Rowell DL (1997) Soil science: methods and applications. Addison Wesley Longman Limited, Essex, pp. 79-108

Sadzawka A, Carrasco MA, Grez R, Mora ML, Flores H, Neaman A (2006) Métodos de análisis recomendados para los suelos de Chile. Revisión 2006. Instituto de Investigaciones Agropecuarias, Serie Actas INIA N ${ }^{\circ} 34$, Santiago, Chile, 164p

Sadzawka A, Carrasco MA, Demanet R, Flores H, Grez R, Mora ML, Neaman A (2007) Métodos de análisis de tejidos vegetales, Segunda edición. Instituto de Investigaciones Agropecuarias, Serie Actas INIA No40, Santiago, Chile, 140p

Saggar S, Andrew RM, Tate KR, Hedley CB, Rodda NJ, Townsend JA (2004) Modelling nitrous oxide emissions from dairy-grazed pastures. Nutr Cycl Agroecosystems 68:243-255. https://doi.org/ 10.1023/B:FRES.0000019463.92440.a3

Salazar F, Martínez-Lagos J, Alfaro M, Misselbrook T (2012) Ammonia emissions from urea application to permanent pasture on a volcanic soil. Atmos Environ 61:395-399. https://doi.org/10.1016/j. atmosenv.2012.07.085

Salazar F, Martínez-Lagos J, Alfaro M, Misselbrook T (2014) Ammonia emission from a permanent grassland on volcanic soil after the treatment with dairy slurry and urea. Atmos Environ 95:591-597. https://doi.org/10.1016/j.atmosenv.2014.06.057

Searle PL (1984) The berthelot or indophenol reaction and its use in the analytical chemistry of nitrogen. A Review Analyst 109:549-568. https://doi.org/10.1039/AN9840900549
Shang Y, Hasan MdK, Ahammed GJ, Li M, Yin H, Zhou J (2019) Applications of nanotechnology in plant growth and crop protection: a review. Molecules 24:2558-2580. https://doi.org/10.3390/ molecules 24142558

Sidorowicz A, Maqbool Q, Nazar M (2019) Future of nanofertilizer. In: Panpatte DG, Jhala YK (eds) Nanotechnology for Agriculture: Crop Production \& Protection. Springer, Singapore, pp 143-152

Sigurdarson JJ, Svane S, Karring H (2018) The molecular processes of urea hydrolysis in relation to ammonia emissions from agriculture. Rev Environ Sci Biotechnol 17:241-258. https://doi.org/10.1007/ s11157-018-9466-1

Silva AGB, Sequeira CH, Sermarini RA, Otto R (2017) Urease inhibitor NBPT on ammonia volatilization and crop productivity: a meta-analysis. Agron J 109:1-13. https://doi.org/10.2134/agron j2016.04.0200

Sun X, Luo N, Longhurst B, Luo J (2008) Fertiliser nitrogen and factors affecting pasture responses. Open Agric J 2:. https://doi.org/ $10.2174 / 1874331500802010035$

Tian H, Xu R, Canadell JG et al (2020) A comprehensive quantification of global nitrous oxide sources and sinks. Nature 586:248-256. https://doi.org/10.1038/s41586-020-2780-0

Torello W, Wehner DJ (1983) Urease activity in a Kentucky bluegrass turf. Agron J 75:654

Ureña-Amate MD, Boutarbouch ND, del Mar Socias-Viciana M, González-Pradas E (2011) Controlled release of nitrate from hydrotalcite modified formulations. Appl Clay Sci 52:368-373. https://doi.org/10.1016/j.clay.2011.03.018

Vistoso E, Alfaro M, Saggar S, Salazar Sperberg F (2012) Effect of nitrogen inhibitors on nitrous oxide emissions and pasture growth following an autumn application in a volcanic soil. Chil J Agric Res 72:133-139. https://doi.org/10.4067/S0718-5839201200 0100021

Wright AF, Bailey JS (2001) Organic carbon, total carbon, and total nitrogen determinations in soils of variable calcium carbonate contents using a Leco CN-2000 dry combustion analyzer. Commun Soil Sci Plant Anal 32:19-20, 3243-3258. https://doi.org/ 10.1081/CSS-120001118

Zulfiqar F, Navarro M, Ashraf M, Akram NA, Munné-Bosch S (2019) Nanofertilizer use for sustainable agriculture: advantages and limitations. Plant Sci 289:110270. https://doi.org/10.1016/j.plant sci.2019.110270

Publisher's Note Springer Nature remains neutral with regard to jurisdictional claims in published maps and institutional affiliations. 